\title{
10: 126839019-126667391
}

National Cancer Institute

\section{Source}

National Cancer Institute. 10:126839019-126667391. NCI Thesaurus. Code C42016.

Physical location of CTBP2_Gene 